Yasser Sakr Jean-Louis Vincent

\title{
Should red cell transfusion be individualized? Yes
}

Received: 18 June 2015

Accepted: 23 June 2015

Published online: 7 July 2015

C) Springer-Verlag Berlin Heidelberg and ESICM 2015

For a contrasting viewpoint, please go to

doi:10.1007/s00134-015-3948-1.

\section{Y. Sakr}

Department of Anesthesiology and Intensive Care, Uniklinikum

Jena, Jena, Germany

J.-L. Vincent (

Department of Intensive Care, Erasme Hospital, Université libre de Bruxelles, Route de Lennik 808, 1070 Brussels, Belgium e-mail: jlvincen@ulb.ac.be

Tel.: 003225553380

\section{Introduction}

Anemia is common in critically ill patients admitted to the intensive care unit (ICU) and is associated with a poorer outcome $[1,2]$. However, red blood cell (RBC) transfusion can have complications and its availability is limited. Hence, one has to find a balance between the risks of anemia and the risks of transfusion. This decision process should be individualized and based on more than a hemoglobin level.

\section{What is the evidence?}

The landmark Transfusion Requirements In Critical Care (TRICC) trial [3] showed similar mortality rates in 838 critically ill patients randomized to a liberal transfusion strategy (hemoglobin levels $10-12 \mathrm{~g} / \mathrm{dl}$ ) or a restrictive strategy (hemoglobin levels $7-9 \mathrm{~g} / \mathrm{dl}$ ). The study was stopped prematurely because of difficulties in recruitment [3]; indeed, only $15 \%$ of the screened patients were enrolled. Importantly, mortality rates were higher in patients in the liberal than in the restrictive arm of the study in the subgroups of younger (age $<55$ years) and less sick (APACHE II score $\leq 20$ ) patients. A post hoc review indicated that patients with ischemic heart disease and those with higher APACHE II scores in the liberal transfusion group had lower mortality rates [4]. Hence, although at first sight it seems that there were no differences in outcome, this is not true when the results are examined further.

Moving to the most recent large randomized controlled trial (RCT) on transfusions after cardiac surgery [5], the global composite outcome, including primarily infectious complications, was similar in the liberal (hemoglobin levels $>9 \mathrm{~g} / \mathrm{dl}$ ) and the restrictive (hemoglobin levels $7.5-9 \mathrm{~g} / \mathrm{dl}$ ) treatment arms, but mortality was higher in patients randomized to restrictive transfusion (4.2 vs. $2.6 \%, p=0.045$ ). This raises serious concerns about the safety of restrictive transfusion in these patients. A recent RCT in cancer patients undergoing major surgery [6] showed that a liberal transfusion strategy with a hemoglobin trigger of $9 \mathrm{~g} / \mathrm{dl}$ was associated with fewer major postoperative complications compared with a restrictive strategy.

Another recent RCT, the Transfusion Requirements In Septic Shock (TRISS) trial, investigated the impact of liberal versus restrictive transfusion strategies on outcome in 1005 patients with septic shock [7]: 90-day survival rates were similar between groups. Transfusion rates were very high in the liberal arm (98.8 vs. $63.9 \%$ in the restrictive arm). The presence of a strict protocol to achieve certain hemoglobin levels irrespective of the patient's general condition may lead to inappropriately high rates of transfusion. Accordingly, whether the results of this study are applicable in current practice is debatable. 
Observational trials have the advantage, compared to randomized studies, that all patients are included, but it is difficult to separate the harmful effects of transfusion per se from the harmful effects of the complication for which the transfusion was indicated. This was nicely illustrated in a study of patients after cardiac surgery, in which the authors convincingly showed that the increased mortality was due to bleeding, which required more transfusions, rather than to the transfusions [8]. It was also well illustrated in a study by Ruttinger et al. [9], in which a simple analysis including only a few variables showed that transfusions were associated with a worse outcome, but this difference disappeared when more variables were included in the analysis. Likewise, in a study of more than 5000 patients after CABG surgery [10], transfusions were associated with reduced long-term survival, but this difference disappeared when the preoperative hemoglobin and estimated glomerular filtration rate were taken into account.

Earlier observational trials raised more concerns than more recent ones about the association between RBC transfusion and poor outcome in critical illness. In an early epidemiological survey of 3534 patients admitted to 146 western European ICUs [2], RBC transfusion was found to be an independent risk factor for death after adjusting for possible confounding factors and in a propensity score-matched analysis [2]. Similar results were reported in trauma patients [11], in patients with burns [12], in patients undergoing cardiac surgery [13], and in patients with acute coronary syndromes [14]. More recent observational studies [1,15] gave different results. In a post hoc analysis of the Sepsis Occurrence in Acutely ill Patients (SOAP) database, including 3147 ICU patients from 24 European countries, blood transfusion was not associated with a higher risk of death in a multivariable analysis and, in 821 pairs matched according to a propensity score, 30-day survival was higher in patients who received blood transfusions than in those who did not [15]. This finding does not support the view that blood transfusions, as currently administered, are associated with increased mortality rates in acutely ill patients. Another study in 5925 postoperative patients admitted to a surgical ICU in Germany reported that blood transfusion was independently associated with a lower risk of inhospital death, especially in patients aged from 66 to 80 years, in patients admitted to the ICU after non-cardiovascular surgery, in patients with higher severity scores, and in patients with severe sepsis [1] (Fig. 1). Likewise, Park and colleagues [16] reported that RBC transfusion was associated with a lower risk of mortality in patients with severe sepsis.

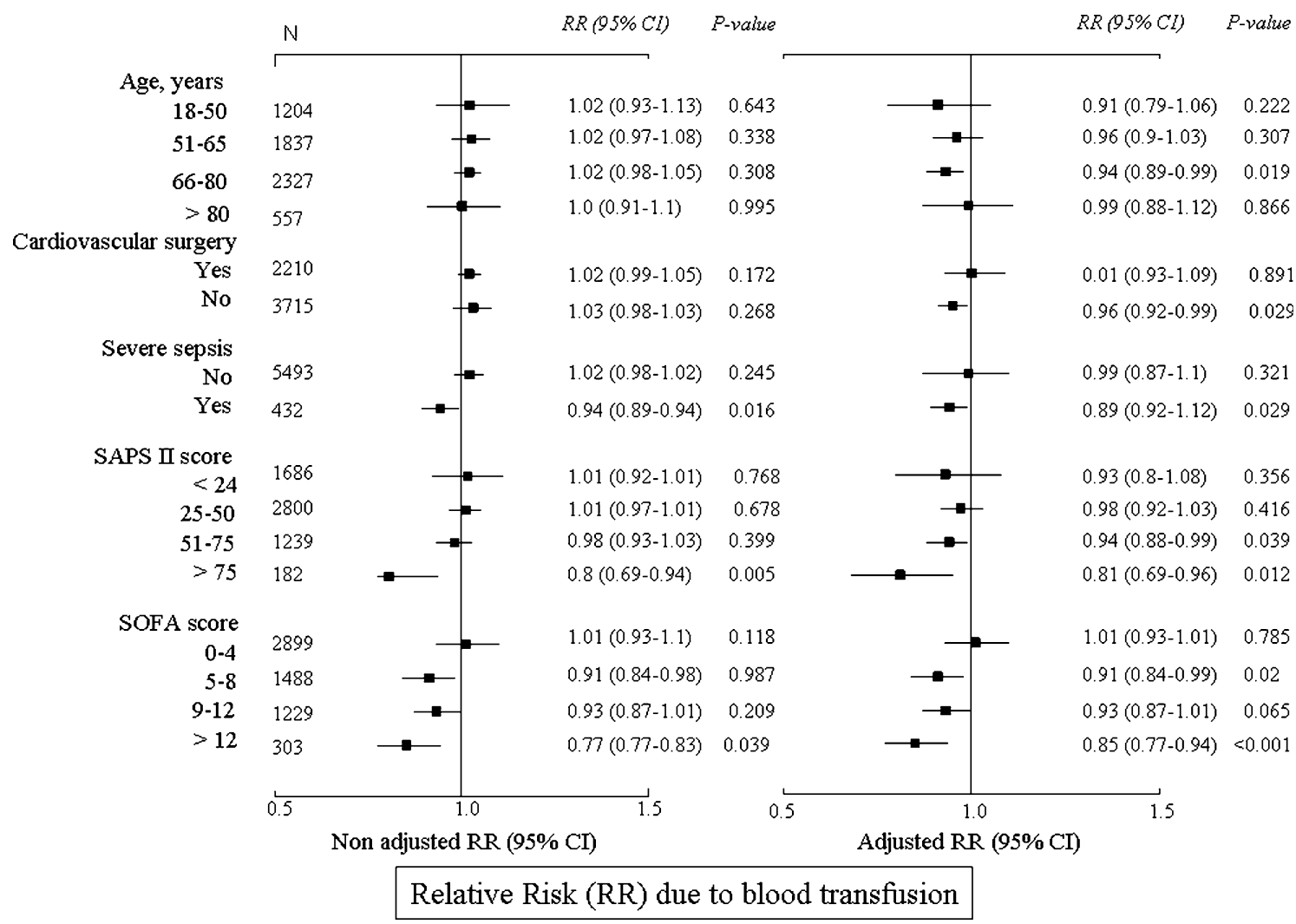

Fig. 1 Relative risk (RR) of in-hospital death due to blood transfusion in selected subgroups of ICU patients. Reproduced from [1]. CI confidence interval, SAPS Simplified Acute Physiology Score, SOFA Sequential Organ Failure Assessment 
These differences between the results of earlier and more recent observational studies may be explained by changes in transfusion practice, especially the implementation of leukoreduction with subsequent reduction in the rate of transfusion-related immunosuppression. In addition, the more restrictive transfusion strategies applied after the publication of the TRICC trial [3] may have become too restrictive in severely ill patients who are most likely to benefit from this therapy.

\section{The case against using hemoglobin levels to trigger transfusion}

The ultimate goal of RBC transfusion is to improve oxygen delivery to the tissues. Hemoglobin levels are readily available at the bedside but are not a surrogate for oxygen delivery and may not be sufficient to reflect adequate tissue perfusion or cellular metabolic needs. In a study of the sublingual microcirculation in patients with severe sepsis [17], we showed that blood transfusion differentially improved microvascular perfusion in patients with impaired baseline perfusion, suggesting that transfusions may be particularly useful in this subset of patients. The clinical decision concerning blood transfusion should be based on a global assessment of the patient's condition, including measures of tissue oxygenation, when available, and comorbidities [18]. Future research on the subject should consider patient diversity and develop more individualized approaches for blood transfusion that are more likely to decrease the risk-tobenefit ratio.

Acknowledgments No external funding.

Conflicts of interest The authors have no conflicts of interest.

\section{References}

1. Sakr Y, Lobo S, Knuepfer S, Esser E Bauer M, Settmacher U, Barz D, Reinhart K (2010) Anemia and blood transfusion in a surgical intensive care unit. Crit Care 14:R92

2. Vincent JL, Baron JF, Reinhart K, Gattinoni L, Thijs L, Webb A, MeierHellmann A, Nollet G, Peres-Bota D, ABC (Anemia and Blood Transfusion in Critical Care) Investigators (2002) Anemia and blood transfusion in critically ill patients. JAMA 288:1499-1507

3. Hebert PC, Wells G, Blajchman MA, Marshall J, Martin C, Pagliarello G, Tweeddale M, Schweitzer I, Yetisir E (1999) A multicenter, randomized, controlled clinical trial of transfusion requirements in critical care.

Transfusion Requirements in Critical Care Investigators, Canadian Critical Care Trials Group. N Engl J Med 340:409-417

4. Deans KJ, Minneci PC, Suffredini AF, Danner RL, Hoffman WD, Ciu X, Klein HG, Schechter AN, Banks SM, Eichacker PQ, Natanson C (2007) Randomization in clinical trials of titrated therapies: unintended consequences of using fixed treatment protocols. Crit Care Med 35:1509-1516

5. Murphy GJ, Pike K, Rogers CA, Wordsworth S, Stokes EA, Angelini GD, Reeves BC, TITRe2 Investigators 2015 (2015) Liberal or restrictive transfusion after cardiac surgery. N Engl J Med 372:997-1008

6. de Almeida JP, Vincent JL, Galas FR, de Almeida EP, Fukushima JT, Osawa
EA, Bergamin F, Park CL, Nakamura RE, Fonseca SM, Cutait G, Alves JI, Bazan M, Vieira S, Sandrini AC, Palomba H, Ribeiro U Jr, Crippa A, Dalloglio M, Diz Mdel P, Kalil Filho R, Auler JO Jr, Rhodes A, Hajjar LA (2015) Transfusion requirements in surgical oncology patients: a prospective, randomized controlled trial. Anesthesiology 122:29-38

7. Holst LB, Haase N, Wetterslev J, Wernerman J, Guttormsen AB, Karlsson S, Johansson PI, Aneman A, Vang ML, Winding R, Nebrich L, Nibro HL, Rasmussen BS, Lauridsen JR, Nielsen JS, Oldner A, Pettila V, Cronhjort MB, Andersen LH, Pedersen UG, Reiter N, Wiis J, White JO, Russell L, Thornberg KJ, Hjortrup PB, Muller RG, Moller MH, Steensen M, Tjader I, Kilsand K, Odeberg-Wernerman S, Sjobo B, Bundgaard H, Thyo MA, Lodahl D, Maerkedahl R, Albeck C, Illum D, Kruse M, Winkel P, Perner A, TRISS Trials Group, Scandinavian Critical Care Trials Group (2014) Lower versus higher hemoglobin threshold for transfusion in septic shock. N Engl J Med 371:1381-1391

8. Dixon B, Santamaria JD, Reid D, Collins M, Rechnitzer T, Newcomb AE, Nixon I, Yii M, Rosalion A, Campbell DJ (2013) The association of blood transfusion with mortality after cardiac surgery: cause or confounding? Transfusion 53:19-27

9. Ruttinger D, Wolf H, Kuchenhoff $\mathrm{H}$, Jauch KW, Hartl WH (2007) Red cell transfusion: an essential factor for patient prognosis in surgical critical illness? Shock 28:165-171

10. Dardashti A, Ederoth P, Algotsson L, Bronden B, Luhrs C, Bjursten H (2011) Blood transfusion after cardiac surgery: is it the patient or the transfusion that carries the risk? Acta Anaesthesiol Scand 55:952-961

11. Malone DL, Dunne J, Tracy JK, Putnam AT, Scalea TM, Napolitano LM (2003) Blood transfusion, independent of shock severity, is associated with worse outcome in trauma. J Trauma 54:898-905

12. Palmieri TL, Caruso DM, Foster KN, Cairns BA, Peck MD, Gamelli RL, Mozingo DW, Kagan RJ, Wahl W, Kemalyan NA, Fish JS, Gomez M, Sheridan RL, Faucher LD, Latenser BA, Gibran NS, Klein RL, Solem LD, Saffle JR, Morris SE, Jeng JC, Voigt D, Howard PA, Molitor F, Greenhalgh DG, American Burn Association Burn Multicenter Trials Group (2006) Effect of blood transfusion on outcome after major burn injury: a multicenter study. Crit Care Med 34:1602-1607

13. Koch CG, Li L, Duncan AI, Mihaljevic T, Cosgrove DM, Loop FD, Starr NJ, Blackstone EH (2006) Morbidity and mortality risk associated with red blood cell and blood-component transfusion in isolated coronary artery bypass grafting. Crit Care Med 34:1608-1616

14. Rao SV, Jollis JG, Harrington RA, Granger CB, Newby LK, Armstrong PW, Moliterno DJ, Lindblad L, Pieper K, Topol EJ, Stamler JS, Califf RM (2004) Relationship of blood 
transfusion and clinical outcomes in patients with acute coronary syndromes. JAMA 292:1555-1562

15. Vincent JL, Sakr Y, Sprung C, Harboe S, Damas P (2008) Are blood transfusions associated with greater mortality rates? Results of the Sepsis Occurrence in Acutely Ill Patients study. Anesthesiology 108:31-39

16. Park DW, Chun BC, Kwon SS, Yoon YK, Choi WS, Sohn JW, Peck KR, Kim
YS, Choi YH, Choi JY, Kim SI, Eom JS, Kim HY, Cheong HJ, Song YG, Choi HJ, Kim JM, Kim MJ (2012) Red blood cell transfusions are associated with lower mortality in patients with severe sepsis and septic shock: a propensity-matched analysis. Crit Care Med 40:3140-3145

17. Sakr Y, Chierego M, Piagnerelli M, Verdant C, Dubois MJ, Koch M, Creteur J, Gullo A, Vincent JL, De
Backer D (2007) Microvascular response to red blood cell transfusion in patients with severe sepsis. Crit Care Med 35:1639-1644

18. Vincent JL (2012) Indications for blood transfusions: too complex to base on a single number? Ann Intern Med 157:71-72 